\title{
CONTEMPORARY ISSUES OF ENFORCEMENT Process IN UKRAINE: DOMESTIC AND INTERNATIONAL APECTS
}

Accepted
28. 4.2021
Revised
29. 10. 2021
Published
22. 12. 2021

Keywords international, enforcement process, enforcement procedure, civil procedure, enforcement document, foreign element, recognition and enforcement of foreign arbitral awards, coercive enforcement, foreign party, enforcement agent
FURSA SVITLANA YAROSLAVIVNA, ${ }^{1}$ MALSKYY MARKIAN MARKIANOVYCH, ${ }^{2,3}$ FURSA YEVHEN YEVHENOVYCH ${ }^{4} \&$ FURSA YEVHEN IVANOVYCH ${ }^{5}$

1 Taras Shevchenko National University of Kyiv, Institute of Law, Department of Notary, Enforcement Process and Advocacy, Prosecution, Judiciary, Kyiv, Ukraine. E-mail: fursa_2003@ukr.net

2 Arzinger Law Firm, Kyiv, Ukraine.

E-mail: Markian.Malskyy@arzinger.ua

${ }^{3}$ Consul of the Republic of Austria, Lviv, Ukraine.

E-mail: Markian.Malskyy@arzinger.ua

${ }^{4}$ Consulate General of Ukraine, Dusseldorf, Germany.

E-mail: fursamfa@gmail.com

${ }^{5}$ Kyiv National University of Trade and Economics, Department of International, Civil and Commercial Law, Kyiv, Ukraine.

E-mail: fursa_2003@ukr.net

CORRESPONDING AUTHOR

fursa_2003@ukr.net

Abstract This article is devoted to the particularities of enforcement process theory and the analysis of international acts and national legislation that govern coercive enforcement of decisions of courts and other bodies (official persons) with a foreign element. The place of international enforcement procedure within the legal system is analysed together with its interconnection with the other branches of law, in particular with private international law, international civil procedure and enforcement procedure. It is suggested that international enforcement procedure should be recognised as a sub-branch of enforcement procedure. The sources of international enforcement procedure were characterised as well, in particular: Global enforcement code, bilateral and multilateral international agreements, European Court of Human Rights case law, Ukrainian court case law, etc. 


\section{$1 \quad$ Introduction}

There is no doubt that legal order and legal confidence are the force behind economic development. Primarily, investments and trade demand suitable instruments for their regulation and, what matters the most, protection, which should thus be the focus of the legal development process. Law enforcement and judicial systems, in particular, are responsible for this mission, and the only way to accomplish it is through legal reforms and effective application. Even the most effective law remains unexecuted if there are no real and practical mechanisms for its implementation that include effective and fair means of coercion, free of legal collisions and gaps. It concerns not only the courts and other authorities that render obligatory acts but also private authorised institutions - arbitrators. These regulations will not have any practical meaning if there is no efficient way to enforce them. Further difficulties arise if the enforcement includes a foreign element.

From this perspective, it is important to address the issue of determining the place of enforcement of decisions and other acts with a foreign element within the legal system.

\section{$2 \quad$ Methodology section}

The objective of this article lies in determining the place of the international enforcement procedure within the legal system through the analysis of its legal nature and connections with other branches of law. The object of this research is formed by relationships between authorities and other persons in the process of coercive enforcement of court decisions and other enforcement acts with a foreign element. The subject of this research is the enforcement procedure that regulates the enforcement of court decisions and other enforcement acts with a foreign element.

The research was conducted with the use of several scientific methods. Problems of social sense and legal form were analysed with the help of the dialectic method. The systematic structural method was used for the conceptual illustration of issues concerning the enforcement of court decisions and other acts with a foreign element. The comparative legal method was used to analyse national legislation in connection with international acts and the European Court of Human Rights case law. The historical method was used to research the development of the national and 
international enforcement procedures. Furthermore, other methods such as analysis and synthesis, deduction, induction, comparison and contradistinction were used to systematise the researched material and draw necessary conclusions.

\section{The definition of the international enforcement procedure}

\subsection{The issue of terminology}

Unfortunately, many Ukrainian and foreign authors disregard the aspect that enforcement procedure has evolved into a separate branch of law in Ukraine, focusing their attention on the recognition of foreign decisions or arbitral awards by national courts. The idea that the whole point of enforcement procedure is confined to enforcement of national courts' decisions concerning foreign citizens or foreign court decisions relating to natural persons and legal entities living in the state where the decision is being enforced (Barihin, 2010: p. 284-285) only serves as a confirmation of this statement.

Enforcement procedure that includes a foreign element can be called "enforcement procedure with a foreign element", "international enforcement procedure", and otherwise. In our opinion, it is more expedient to use the term "international enforcement process" since the term "international" has gained the most recognition in legal practice and doctrine. At the same time, it is universal because it includes relationships not only with one but with an indefinite circle of foreign elements. Despite the fact that the terms "cross-border" and "transnational" are being used in theoretical sources, legal documents, and legal vocabulary, the name for this process should be unambiguous so that its definition would be clear and acknowledged.

The term "cross-border" is widely used, especially in foreign legal literature, to describe the movement within and across the state borders, for example, crossborder insolvency, cross-border bankruptcy. The term "transnational" is more similar to the term "international", but it is important to differentiate them. Both international and transnational law govern issues concerning different jurisdictions; however, transnational law has a broader meaning on the global scale. At the same time, norms of transnational law, contrary to the norms of international law, are not always obligatory and can be of a recommendatory, "soft" nature. 
The term "transnational" was suggested by F. Jessup (Jessup, 1956: p. 14-15). He perceived the concept of transnational law as a totality of legal norms that regulate actions or events that exceed national borders and include both public and private international norms together with other norms that are not a part of those standard categories. There is a noteworthy idea for the interpretation of the term "transnational law" that is popular among scholars of the post-soviet space. Specifically, V. Shumilov (2001) states that transnational law can be defined as a set of norms that regulate actions or events that exceed national borders, and, in particular, relationships of international nature that cannot be governed only by international law, nor only by national law. We share this idea since it allows a conclusion that not everything is regulated yet, and there is still much work to be done in this area.

In the case of enforcement of decisions and other acts with a foreign element, norms of national, foreign and international law apply. Accordingly, rules and proceedings that govern this process form the international enforcement procedure (i.e. the enforcement procedure with a foreign element).

\subsection{The terminology of international enforcement procedure in Ukrainian legislation}

The necessity to regulate enforcement of decisions of courts and other authorities with a foreign element has caused the merging of legal regulations in two different legal areas - enforcement procedure and private international law - as well as the creation of new norms to govern these relationships since these norms are scattered across different branches of both national and international law. The lack of unified terms has caused a paradoxical situation: the preamble of the Law of Ukraine called "On Private International Law" states that the Law regulates private legal relationships, at least one element of which concerns one or several jurisdictions other than Ukrainian. Article 81 of the same Law implies the possibility of recognition and enforcement of foreign court decisions in Ukraine. In this way, the Law does not guarantee the protection of rights through the recognition and enforcement of foreign decisions but only considers the notion of foreign court decisions that can (potentially) be recognised and enforced in Ukraine. Moreover, the name of the Law leaves room for assumptions that Ukraine governs "private international law", which is inaccurate. This situation is caused by the fact that there 
is no unified definition system in Ukrainian doctrine for lawmakers to use. Thus, part XIII of the Law of Ukraine "On Private International Law" is called "Recognition and enforcement of the decisions of foreign courts"; however, it only includes the list of decisions by foreign courts and authorities that can be recognised and enforced in Ukraine. It fails to describe the order for the enforcement of these decisions and only provides a general reference to Ukrainian legislation. It is not even coordinated with the Civil Procedural Code of Ukraine, even though part IX thereof is called "Recognition and enforcement of the decisions of foreign courts", the same as the one in the Law. The order of enforcement procedure itself is regulated by another Law of Ukraine, "On Enforcement Procedure".

The development and place of international enforcement procedure within the legal system

\subsection{The establishment of enforcement procedure as an independent legal branch and development of its legal meaning}

A controversial issue arises when trying to determine whether norms on recognition and enforcement of foreign court decisions and arbitral awards fall under international civil procedure or international enforcement procedure. In our opinion, recognition and enforcement are two separate institutes of civil and enforcement procedures. Considering the fact that courts are the bodies that recognise and allow further enforcement of a decision, these aspects are certainly a part of the international civil procedure; however, enforcement itself should be considered a part of the international enforcement procedure. Moreover, the recognition of decisions with a foreign element is sought within the judicial procedure, that is, separately from the international enforcement procedure, while the enforcement is carried out in another jurisdiction or even in several jurisdictions. Hence, it is more closely related to the international enforcement procedure. Noteworthy herein is the definition of the term "bringing the court decision in civil cases to enforcement" in regard to the terminology used in international conventions and agreements on the enforcement of arbitral awards, suggested by R. Liashenko (Liashenko, 2013: p. 5). The author views this term as having two aspects: a complex institute of civil and enforcement procedure. The reason for this complexity lies within the fact that the "bringing" includes the allowing of further enforcement, which is regulated by Article 431 of the Civil Procedural Code of Ukraine, while the 
enforcement itself is carried out within the enforcement procedure according to the Law of Ukraine "On Enforcement Procedure". The author also interprets it from another perspective as a "period in time from the moment the decision comes into force to the opening of the enforcement proceedings and the start of its actual enforcement." While this definition only concerns the Ukrainian enforcement procedure, we consider it to be also applicable to the international enforcement procedure.

Historically, enforcement procedure in Ukraine was viewed as a part of judicial procedure. Amongst other reasons, this was based on the fact that it was conducted by court enforcement agents and regulated by the civil procedure. It is important to mention that being a part of the court system, enforcement agents had judicial powers and were close to the position of a judge, while judges, on the other hand, could directly influence enforcement proceedings, which not only made them more authoritative but also allowed for fast enforcement of decisions, though not always a legitimate one. This unrestrained power and its questionable use had laid grounds for further reform of the judicial system.

This interpretation of enforcement procedure was transformed after the Law of Ukraine "On state enforcement agency" was passed in 1998. After a year, the Law of Ukraine "On Enforcement Procedure" was also adopted. It defined the enforcement procedure as a coercive execution of decisions of courts and other authorities that is carried out on the grounds, through the means and within the scope determined by this and other Laws and decisions that are to be enforced under this Law. These new Laws have secured the inter-branch nature of the enforcement procedure and its separation from the judicial system by categorising enforceable documents into court and non-court acts.

However, the Law of Ukraine "On Enforcement Procedure" was flawed in defining the enforcement procedure as a final stage of judicial procedure. Even though it was further described as a compulsory execution of regulations of other authorities, the abovementioned statement has led to the adoption of the concept of enforcement procedure as a stage in judicial procedure. 
The current version of the Law has the same definition, despite implementing the institute of private enforcement agents, who are not a part of the judicial system. Nonetheless, the reform of enforcement procedure that was held in Ukraine between 2015 and 2017 was the most systematic and forward-oriented in the history of enforcement procedure of Ukraine. As one of the initiators of the reform, S. Shkliar (2016) stated in his speech at the conference in Kharkiv that "The place of private enforcement agent in the system of enforcement of court decisions", "the unsatisfactory condition of enforcement of court decisions is the main reason for the reform. The reform of the enforcement agency is an integral part of the judicial reform that the President of Ukraine has determined as a priority for the country."

In the scope of the judicial reform, another important Law of Ukraine "On Bodies and Persons who Carry out the Enforcement of Court Decisions and Acts of Other Authorities" was adopted that, in our opinion, should put an end to the discussion about the place of enforcement procedure in Ukrainian legal system and define it as an independent branch. This Law introduced the institute of private enforcement agents as subjects of private law with authority to enforce court decisions and other acts according to the Law. In this way, the separation of certain bodies and persons from the judicial system and the possibility of enforcement of non-court decisions confirm that this process cannot be viewed as a part of judicial procedure, same as the administrative activity of other authorities, as S. Sherbak stated long before the institute of private enforcement agents was introduced.

\subsection{Characteristic features of enforcement procedure as an independent branch of law}

In that regard, O. Naumenko (Naumenko, 2013) raised the question of how can enforcement procedure be a stage of judicial proceedings if the court is not a part of it (at least until further complications requiring judicial competence arise)? She believes that there are reasons to state that enforcement law is paving its way to becoming a separate branch of law in the Ukrainian legal system. As the relationships in the enforcement procedure form around their "original", uncommon for any other branch, "kernel" of enforcement procedure by adopting other related relationships (commercial procedural, civil procedural, administrative, administrative procedural, etc.), and these are the characteristic features of the object of a complex branch of law, a conclusion can be drawn that the enforcement 
procedure is one. We share the idea about the independence of enforcement law as a branch, although we do not agree with all of the abovementioned arguments. In our opinion, the enforcement procedure does not include commercial, civil and administrative procedural relationships, as these branches are related to the judicial procedure. If the judicial procedure in terms of enforcement procedure is required, it should be viewed as a cooperation of the enforcement body with the court, thus constituting inter-branch relationships. These relationships would not belong solely to the enforcement procedure since they would concern judicial procedure. Even though the debtor, the creditor and the enforcement agent could be the subjects of this procedure, the case (Articles 447-453 of the Civil Procedure Code of Ukraine disputing the decisions, actions or lack of actions of the enforcement agent) or other procedural aspects (Article 435 of Civil Procedure Code of Ukraine - adjournment or instalment of payment, alteration or determination of enforcement measures and procedure) would be considered by the court.

Like most branches of law, enforcement law consists of a general and a special part. O. Isaenkova (2008) and V. Gureev (2009) note that the general part of this branch includes norms and institutes that concern the enforcement procedure in general, its object, methods, principles, subjects, terms, expenses, responsibilities, etc. The special part consists of norms that regulate the movement and development of the enforcement procedure from one stage to another, enforcement peculiarities of different documents, different enforcement actions, recovery of different types of property etc.

In this regard, the concept of S. Fursa (2012) on the structure of notarial discipline is accepted, which categorises the information into two large parts: one concerning the organisational structure of notarial activities and another related to the procedural aspect of notarial activities (notarial procedure). This concept could be used as an analogy for the enforcement procedure: it could be divided into two separate parts - the functioning of enforcement bodies and the theory of enforcement procedure (including comparative aspects of organisation and enforcement in different countries, international enforcement procedure). 


\subsection{International enforcement process as a sub-branch of law}

A legal system is a dynamic formation that consists of several elements: institutes, branches, sub-branches. Determining the place of international enforcement procedure in that system is vital to understanding the meaning of all these elements.

P. Rabinovych (2001) defines a branch of law as a system of legal norms that govern a certain area of public relationships with a specific method of legal regulation. The criteria for dividing norms into branches are: the object of legal regulation (relationships governed by law), the method of legal regulation (a specific way for the state to influence public relationships through legal norms and other legal instruments).

O. Havinska (2017) researched sub-branches of law in the Ukrainian legal system and defined a sub-branch as a relatively autonomous totality of norms that exists within the branch of law, includes several related legal institutes and by demand of legal practice can overcome its lack of institutes and form a separate direction of legal regulation (branch of law). She named specific features of sub-branches that differentiate them from branches and institutes: firstly, the formation of sub-branch is related to the fragmentation of norms, but contrary to the formation of institutes, it is related to the specialisation of legal influence; secondly, it is related to the formation of an additional method of legal regulation that is used as a subsidiary and can replace the main branch method of legal regulation; thirdly, its formation does not occur on the legislative basis, but by the development of autonomous areas of legal practice.

The international enforcement procedure cannot exist separately from the enforcement procedure, and its inter-branch nature is not a strong enough argument to research it outside the scope of enforcement procedure, as they have a common general object and method of regulation.

The object of the regulation of international enforcement procedure is the enforcement of decisions, same as in the national enforcement procedure, but it also has an additional feature: a foreign element. Both national and international enforcement procedures are characterised by the imperative method of regulation; however, it is combined with some aspects of the declarative method that reveals 
itself, for example, in a possibility for the creditor to choose the enforcement body (state or private enforcement agent), except for the cases when the issue cannot be resolved by a private enforcement agent (Article 5(2) of the Law); choose the jurisdiction of enforcement (in some cases); withdraw the enforcement document; refuse to keep the debtor's property that cannot be auctioned if there is no other property that can be collected (Article 37(1.1.3) of the Law of Ukraine "On Enforcement Procedure"); and the possibility for the debtor to suggest which property should be auctioned first (Article 48(5) of the Law) etc.

We can thus state that the international enforcement procedure has characteristic features of a sub-branch of law, namely:

- It includes several legal institutes that belong to the same branch (participation of a foreign citizen or a stateless person in the enforcement procedure; enforcement of decisions and acts issued in foreign countries; carrying out enforcement actions abroad; enforcement of decisions of international courts and non-court institutions);

- It has a structure of norms, united by a foreign element;

- It has a main (imperative) and additional (declarative) method of legal regulation;

- There is an autonomous legal practice of enforcement of court decisions and acts of other authorities with a foreign element.

\section{Sources of the international enforcement procedure}

\subsection{The issue of the definition of sources of the international enforcement procedure}

It is also important to note that the enforcement procedure with a foreign element has to be carried out not only in accordance with the national law but also in compliance with international agreements. Therefore, to ensure the effectiveness and coordination of law enforcement practice, it is crucial to improve its legislative regulation both on national and international levels. 
The issue of sources of the international enforcement procedure is vital for its doctrine yet remains unresearched in Ukraine. For studying this issue, it is important to understand the common definition of sources of law.

A very significant contribution to the definition of the "source of law" was made by N. Parkhomenko (Parkhomenko, 2009: p. 15). She defines sources of law as obligatory acts of authorised subjects of law that include written norms and acts of authorities that create, alter or end legal relationships. She also listed the following features of sources of law: publicity - they are created by law-making subjects and concern all persons under the jurisdiction of the state; formalised nature - they have a particular form or are officially recognised; hierarchy - they form a certain hierarchy according to legal power; direct connection with the state - they are created by the state or with its permission and are sanctioned by the state. This idea is rather normative since its core consists of normative acts, although the element of "law-making" is not excluded.

The traditional sources of law are a normative act, normative treaty, legal custom and legal precedent. R. Topolevsky (Topolevsky, 2004: p. 10) suggests adding to the system of sources of law the non-traditional ones (principles of law, corporate sources of law, religious sources of law, etc.). He also suggests the following division of sources of law: a) basic (fundamental); b) derivative (specific); c) subsidiary.

Russian scholar G. Uliotova (Uliotova, 2007: p. 37) also suggests distinguishing between traditional and non-traditional sources of law. In her opinion, nontraditional sources also include principles and norms of international law, decisions of the Constitutional court and other higher courts of the Russian Federation and decisions of the European Court of Human Rights concerning Russia, which is a very interesting approach. However, this system also fails to include all sources of law.

Ukrainian doctrine distinguishes the terms "source" and "form" of law. Generally, the forms of legal norms are called the sources of law in a formal legal way. However, this interpretation is imprecise as this term can have other meanings. For example, social factors that define legal norms, state as the force that creates law and sources of information about the law (legal instructions, textbooks on law, etc.) can all be sources of law. 
Thus, we believe that the source of international enforcement procedure (defined broader than simply a form of law) is relevant legal information that can have different forms - judicial practice, interpretations, decisions of the Constitutional court of Ukraine, decisions of the European Court of Human Rights - or can be shared verbally, for example during a conference or on the TV, and become widely acknowledged or specified, extended or concretised by experts, etc.

\subsection{The system of sources of the international enforcement procedure}

We suggest the following system of sources of the international enforcement procedure:

1. National legislation

- Ukrainian legislation;

- Legislation of a foreign state applying for the enforcement of a decision;

2. International law

- International agreements Ukraine and a foreign state are parties to;

- Other international documents that regulate enforcement of a decision or an act;

- "Soft law";

3. Case law

- Case law of Ukrainian courts;

- Case law of courts of a foreign state;

- Case law of international courts.

\subsubsection{National legislation}

In regard to Ukrainian national law, considering the point made by Y. Bilousov (Bilousov, 2005), the sources of international enforcement procedure include - in addition to the already mentioned Laws of Ukraine "On Private International Law" of June 23, 2005, "On Enforcement Procedure" of June 2, 2016, "On Bodies and Persons, who Carry out the Enforcement of Court Decisions and Acts of Other Authorities" of June 2, 2016 - Civil Procedure Code, Commercial Procedure Code, Criminal Procedure Code, Criminal Enforcement Code and Code of Administrative 
Offences of Ukraine, which regulate the procedure of "bringing" decisions to enforcement in different branches of law, as well as the Law of Ukraine "On notary activity" of September 9, 1993, which regulates the enforcement of notarial writs, Civil Code, Commercial Code, Family Code of Ukraine and other documents regulating substantive law, regulations of the Cabinet of Ministers of Ukraine and the Ministry of Justice of Ukraine.

\subsubsection{International law}

International treaties form an essential part of the regulation of the international enforcement procedure. The most commonly applied and acknowledged is the New York Convention on Recognition and Enforcement of Foreign Arbitral Awards of June 10, 1958, which about 150 states are parties to. Other international treaties are the European Convention on International Commercial Arbitration of April 4, 1961, the Kyiv Agreement on Settling Disputes Related to Commercial Activities of December 19, 1992, the Minsk Convention on Legal Assistance and Legal Relations in Civil, Family and Criminal Matters of January 22, 1993, and the Washington Convention on the Settlement of Investment Disputes Between States and Nationals of Other States of March 18, 1965.

A notable mention would also be the European Convention on Human Rights of November 4, 1950. This Convention includes norms about the obligatory nature of the European Court of Human Rights decisions (Article 46).

A representative of Western European science P. Kinsch (Kinsch, 2014: p. 544) states, after conducting his analysis of recent decisions of the European Court of Human Rights, that rights guaranteed by the Convention include the right to enforcement of foreign decision and that two natures of its realisation are recognised. Firstly, it can be substantive and based on the rule of recognition of a basic situation, provided that this situation is protected by the Convention norms (for example, Article 8: the right to respect for one's private and family life, his home and his correspondence). Secondly, this right can be procedural and derive from the right to the effectivity of a decision rendered by "any" court. 
T. Shilling shares a similar idea, noting that foreign decisions have to be enforced on the basis of Article 6 under the same conditions as national court decisions. However, the European Court also accepts a recognition procedure. On the one hand, this procedure allows the state to control the fairness of proceedings under Article 6. At the same time, the Court also sets limits to this right of the state by determining grounds on which the state can refuse to recognise the decision (for example, the lack of jurisdiction of a foreign court, a failure to comply with other national requirements for recognition).

We have to agree with P. Kinsch and T. Shilling. Their ideas allow us to conclude that Article 6 of the Convention, which guarantees the right to a fair trial, also includes the right to enforcement of court decisions.

In this regard, important sources also include acts of the European Union (hereinafter: EU), particularly the Brussels Convention on Jurisdiction and the Enforcement of Judgments in Civil and Commercial Matters of September 27, 1968, the Lugano Convention on Jurisdiction and the Enforcement of Judgments in Civil and Commercial Matters of September 16, 1988, the Regulation 44/2001 of EU on Jurisdiction and the Enforcement of Judgments in Civil and Commercial Matters of December 22, 2000, the Regulation 1215/2012 on Jurisdiction and the Enforcement of Judgments in Civil and Commercial Matters of December 12, 2012. The most common enforcement procedures in the EU countries are provided by the Regulation No. 805/2004 of the European Parliament and of the Council of 21 April 2004 creating a European Enforcement Order for uncontested claims, the Regulation No. 1896/2006 of 12 December 2006 creating a European Order for Payment Procedure, the Regulation No. 861/2007 of 11 July 2007 on the European Small Claims Procedure. These documents regulate the recognition and enforcement of court decisions of EU member states in the territory of other EU member states.

Inter-branch agreements can also serve as sources of the international enforcement procedure. Firstly, these are conventions that concern the issues of adoption (the Hague Convention on Protection of Children and Co-operation in Respect of Intercountry Adoption of May 29, 1993, the Inter-American Convention on Conflict of Laws Concerning the Adoption of Minors of May 24, 1984, etc.); secondly, conventions on child support (the New York Convention on the International Recovery of Child Support and Other Forms of Family Maintenance of June 20, 
1956, the Hague Convention on the Law Applicable to Maintenance Obligations of October 2, 1973); and thirdly, conventions on cross-border bankruptcy (the UNCITRAL Model Law on Cross-border Insolvency of May 30, 1997, the European Convention on Certain International Aspects of Bankruptcy of June 5, 1990).

There are also many bilateral international agreements concluded by the countries to regulate certain aspects of legal areas. Ukraine entered into several such agreements concerning the international enforcement procedure with other countries, such as China, Poland, Lithuania, Estonia, Cyprus, etc.

A special place in the system of sources of law is occupied by the "soft law". Sources of "soft law" aim to create common advisory rules that can be further implemented in national legislation. For example, the United Nations Commission on International Trade Law (UNCITRAL) adopts model laws and rules if there are difficulties with achieving a common regulation of norms in a certain area. The Commission adopted several model laws: Model Law on International Commercial Arbitration of December 1985, Model Law on Cross-border Insolvency of May 30, 1997, etc. (Vasylenko, 2013: p. 371).

In the context of the international enforcement procedure, it is important to mention the Global Enforcement Procedure Code, issued by the International Union of Judicial Officers (UIHJ) in 2015. Even though the Code consists of advisory norms and can hardly be considered a source of law in a conventional sense, it is unwise to underestimate its importance for national legislation and sharing of experience between countries. V. Yarkov (Yarkov, 2017: p. 43) calls this document an example of "soft law" that combines the most common and important aspects in the area of the enforcement procedure, which are characteristic of national enforcement systems in certain states.

\subsubsection{Case law}

A special source of international enforcement procedure are the decisions of the European Court of Human Rights. Article 17 of the Law of Ukraine "On Enforcement of Decisions and Implementation of the Practice of European Court on Human Rights" unambiguously states that "courts use the Convention and case 
law of the Court as a source of law". At the same time, we share the perspective of scholars (Liashenko, 2017) who believe that decisions of the European Court cannot always comply with the Ukrainian legal system and may not always be right. It is important to realise that these decisions depend on the situation, as they are based on the analysis of courts' positions, while court decisions, claimants' and state representatives' standpoints are subjective. Many factors are thus influenced by the qualifications of representatives in the adversarial system. Therefore, it is evident that not all decisions of the European Court can be viewed as "exemplary" or "ideal" sources of law. They should be thoroughly analysed before they can be used as a source of law. Moreover, the position of the European Court is not always sustainable and can be altered by the Court itself.

In Y. Bilousov's (Bilousov, 2005: p. 14) opinion, which also considers decisions of the Constitutional Court of Ukraine, the following should be included in the system of sources of international enforcement procedure:

- The decision in the case initiated by 47 national deputies of Ukraine on the compliance with the Constitution of Ukraine (constitutionality) of the Law of Ukraine "On Moratorium for Compulsory Acquisition of Property" of June 10, 2003;

- The decision in the case initiated by Joint venture "Mukachivskyi plodoovochevyi konservnyi zavod" on the official interpretation of Article 3(10) of the Law of Ukraine "On Enforcement Procedure" of February 24, 2004.

We share this view and would like to expand this list with the decision of the Constitutional Court of Ukraine in the case initiated by Shareholders Company "Kharkivoblenergo" on the official interpretation of Article 17(2.2), Article 26(1.1), Article 50(1) of the Law of Ukraine "On Enforcement Procedure" of June 26, 2013; the decision in the case initiated by "DID Cons", Ltd. on the official interpretation of Article 37 (1.15) of the Law of Ukraine "On Enforcement Procedure" in relation to Article 41(1), Article 124(5), Article 129(3.9) of the Constitution of Ukraine, Article 115 of the Commercial Procedure Code of Ukraine, Article 1(1.3, 1.4), Article 2(2), Article 3(3.7.6) of the Law of Ukraine "On Measures Aimed for Sustainable Functioning of Fuel and Energy Complex Companies" of December 13, 2012. 


\section{Relevant practical issues concerning the international enforcement procedure}

\subsection{The lack of regulatory norms on the international enforcement procedure}

It is impossible to miss the fact that the Law of Ukraine "On Enforcement Procedure" does not contain a separate part, nor a set of norms that regulate international enforcement procedure or enforcement with a foreign element. Even though part XII of the Law is called "Enforcement of decisions concerning foreign citizens, stateless persons and foreign legal entities. Enforcement of foreign court decisions", its norms are not particularly informative. Specifically, the same conditions apply to foreign subjects (foreign citizens, stateless persons and foreign legal entities) and Ukrainian citizens. The only difference is the possibility to impose special coercive measures in the case of a failure to execute the decision and/or comply with the demands of the enforcement agent. Thus, according to Article 77 of the Law, in the case of a failure to execute the decision, the enforcement agent is entitled to turn to authorities with a request for the entry ban or deportation of such persons, according to the Law of Ukraine "On the legal status of foreign citizens and stateless persons". Therefore, the current version of Article 77 of the Law is ambiguous because it fails to consider the possibility of enforcing decisions concerning foreign citizens in the territory of one or several foreign countries.

However, Article 78 of the Law states that foreign court decisions shall be recognised and enforced in the territory of Ukraine in accordance with international agreements Ukraine is a party to and with Ukrainian legislation if the recognition and enforcement of these decisions are foreseen under international agreements or based on the reciprocity principle. Thus, the combined analysis of Articles 77 and 78 of the Law allows us to conclude that these norms are not coordinated, as they provide certain benefits to foreign debtors who can avoid enforcement by leaving the country.

We deem it necessary to include norms in Article 77 of the Law that would also allow the enforcement agent to initiate the recovery of financial and other assets of the debtor located outside of Ukraine, in addition to requesting the decision on the entry ban or deportation of a foreign debtor, as long as such option is provided 
under bi- or multilateral agreements that both Ukraine and the state where assets are located are parties to. It is also important to further develop this mechanism to ensure the cooperation of relevant authorities concerning that matter. This would ensure successful enforcement rather than equip debtors with instruments to evade responsibility.

\subsection{Issues of maritime law in connection with the international enforcement procedure}

Interesting for further analysis and relatively new for the Ukrainian legal system is the case where the court has to authorise the seizure of a ship that carries quickly perishable goods belonging to a person who is not an owner of the ship as an injunction or enforcement measure. On the one hand, the seizure of a ship as an injunction in a maritime claim is allowed under Articles 137(1.9, 2) of the Commercial Procedural Code and 150(1.9, 5) of the Civil Procedural Code, but on the other hand, it is prohibited to seize quickly perishable goods. A collision thus occurs that requires, in our view, considering the opinion of foreign scientists, since the owner of goods may sustain considerable damage caused by the spoiling of said goods in the case of a prolonged seizure of the ship. Accordingly, a seizure can be authorised in a port where the ship is unloaded and quickly perishable goods are discharged. In our opinion, the seizure cannot be authorised in other ports of Ukraine through which the ship will pass in transit if that would prevent a prompt delivery of goods. At the same time, we believe that it is impossible to impose a duty upon private or state enforcement agents to reload quickly perishable goods and transfer them to the correct address since that is not a part of their commission and would render them liable for certain risks.

If a loaded ship is delayed as a result of the attempt to seize it, we believe that the owner of the ship should be represented by a counsel who would draft an act of maritime protest, as the ship's delay could prevent a prompt delivery of goods and cause damage to the charterer. In our opinion, the ship's recovery may occur in another port under such circumstances, but only within the scope of the principle of proportionality, according to which coercive enforcement of court decisions may not cause considerable damage to the rights and interests of third parties. Therefore, these issues should be widely discussed before their implementation. 
Nevertheless, one issue is already obvious - Ukraine does not have a special trade network or marketplace where quickly perishable goods could be sold promptly. Thus, it is evident that the seizure of said goods remains impossible, while another issue of how the recovery of such goods can be carried out remains unsolved. In our opinion, it is necessary to create and popularise a platform where quickly perishable goods could be auctioned.

\section{$7 \quad$ Conclusions}

All of the above allows us to conclude that there is still plenty to be done in the area of the international enforcement procedure. Although the national enforcement procedure has received enough recognition through the years of reforms to be considered an independent branch of law, the issue of enforcement procedure with a foreign element has sadly not been implemented either in the structure of international enforcement procedure or in the civil or enforcement procedure, meaning that such an important relationship not only remains ungoverned by the state but also evades the focus of scholars.

The analysis of norms and relationships concerning the international enforcement procedure has led us to conclude that there is insufficient ground to define it as an independent branch of law or to analyse it outside the scope of the national enforcement procedure since they have the same object and method of regulation. The object of norms regulating international enforcement procedure was determined as coercive enforcement, like in the enforcement procedure, but with a notable difference; the subject of the international enforcement procedure is additionally characterised by one common feature - a foreign element. After a thorough analysis of said relationships, we can confidently state that the international enforcement procedure is a sub-branch of the enforcement procedure.

We have also researched the issue of sources of the international enforcement procedure, as their system remains unresearched in Ukrainian doctrine. The analysis allowed us to suggest a structure of sources that can be considered sources of international enforcement procedure, including national legislation, international treaties and "soft law", as well as case law of national and international courts. 
The analysis of some current issues of Ukrainian legislation governing the international enforcement procedure has led us to conclude that it is crucial to research practical aspects of enforcement in connection with different branches of law. The problem with the recovery of ships carrying quickly perishable products has demonstrated that Ukrainian legislation does not consider all practical issues arising within the enforcement procedure, so it is important to raise discussions on the matter to stimulate relevant legislative changes in the area.

\section{References}

Barihin, A. B. (2010). Bol'shaja juridicheskaja enciklopedija [Big legal dictionary] (Moscow: Knizhnyj mir). Bilousov, Y. V. (2005). Vykeonavche provadzhennia: navch. posibnyk [Enforcement procedure: textbook] (Kyiv: Pretsedent).

Fursa, S. Y., Fursa, Y. I., Bondarieva, M. V. and others (2012). Teoriia notarialnobo protsesu: nauk.-prakt. posibnyk. [The theory of notary procedure: scientific and practical textbook] (Kiev, Alerta: Tsentr uchbovoi literatury).

Gureev V. A., Gushin V.V. (2009) Ispolnitel'noe proizvodstvo: uchebnik [Enforcement procedure: textbook] (Moscow: Eksmo).

Havinska, O. A. (2017). Pidhaluæi prava v systemi prava suchasnoi Ukrainy: avtoref. dys. na zdobuttia nauk. stupenia kand. yuryd. nauk: 12.00.01 "Teoriia ta istoriia der₹havy i prava; istoriia politychnykh i pravorykh vchen" [Sub-branches of law in the legal system of modern Ukraine: The Abstract of the Thesis for a Candidate Degree in Legal Sciences: 12.00.01 "Theory and history of law and state; history of political and legal sciences"] (Odesa: IHU).

Isaenkova, O. V., Balashov, A. N., Balashova, I. N. (2008). Ispolnitel'noe proizvodstvo v Rossijskoj Federacii. Kurs lekcij: ucheb. posobie dlja VUZov [Enforcement procedure in Russian Federation, Lecture course: textbook for Higher-educational institutions] (Moscow, Gross Media: ROSBUH).

Jessup, Ph. C. (1956). Transnational Law. (New Haven: Yale University Press).

Kinsch, P. (2014). Enforcement as a Fundamental Right. Nederlands Internationaal Privaatrecht [Dutch Private International Law], No. 4, 540-544.

Liashenko, N. A. (2017). Zastosuvannia praktyky Yevropeiskoho sudu z prav liudyny pry rozghliadi tsyvilnykb sprav: avtoref. dys. na zdobuttia nauk. stupenia kand. yuryd. nauk: 12.00.03 "Tsyvilne pravo $i$ tsyvilnyi protses; simeine pravo; mizhnarodne pryvatne pravo" [The application of the European Court on Human Rights practice in civil cases: The Abstract of the Thesis for a Doctorate Degree in Juridical Science: 12.00.03 "Civil law and civil procedure, family law, private international law"] (Kyiv: TSNUK).

Liashenko, R. O. (2013). Pryvedennia sudovykh rishen u tsyvilnykh spravakh do prymusovoho vykonannia: avtoref. dys. na zdobuttia nauk. stupenia kand. yuryd. nauk: 12.00.03 "Tsyvilne pravo i tsyvilnyi protses; simeine pravo; mizhnarodne pryvatne pravo" [Coercive enforcement of court's decisions in civil cases: The Abstract of the Thesis for a Candidate Degree in Juridical Science: 12.00.03 "Civil law and civil procedure, family law, private international law"] (Kyiv, TSNUK).

Naumenko, O. M. (2013). Sudova kontseptsiia vykonavchoho provadzhennia: krytychnyi analiz [Court's concept of enforcement procedure: critical analysis]. Visnyk. Kyivskoho natsionalnoho universytetu imeni Tarasa Shevchenka. Yurydychni nauky [Bulletin of TSNUK. Juridical Sciences], No. 3, 81-85, retrieved from: http://nbuv.gov.ua/UJRN/VKNU_Yur_2013_3_17.

Parkhomenko, N. M. (2009). D₹herela prava: teoretyko-metodolobichni zasady: avtoref. dys. na zdobuttia naukovoho stupenia d-ra yuryd. nauk: 12.00.01 "Teoriia ta istoriia derzhavy i prava: istoriia politychnykh $i$ pravovykh uchen" [Sources of law: theoretical and methodological basis: The Abstract of the 
Thesis for a Doctorate Degree in Juridical Science: 12.00 .01 "Theory and history of law and state; history of political and legal sciences"] (Kyiv: V.M. Koretsky Institute of State and Law of NASU).

Rabinovych, P. M. (2001). Osnovy zahalnoi teorii prava ta derzhavy: navch. posibnyk. Vyd. 5-te, zi zminamy [Basics of the general theory of law and state: textbook. $5^{\text {th }}$ edition, revised] (Kyiv: Atika).

Shkliar, S. (2016). Reforma vykonavchoi sluzhby ye nevid'iemnoiu chastynoin sudovoi reformy [The reform of enforcement service is an integral part of the judicial reform]. Ministerstvo yustytsii Ukerainy: ofitsiinyi sait [The Ministry of Justice of Ukraine: official website], retrieved from: https://minjust.gov.ua/news/ministry/reforma-vikonavchoi-slujbi-e-nevidemnoyuchastinoyu-sudovoi-reformi---sergiy-shklyar-23160.

Shumilov, V. M. (2001). Miəhnarodne publichne ekonomichne pravo: navch. posibnyk. Vyd. 2-he, vypr. i dopov. [International public economic law: Textbook, 2nd Ed., revised and updated] (Moscow: Nymp), retrieved from: http://bibliograph.com.ua/mezhdunarodnoe-pravo-4/index.htm.

Topolevsky, R. B. (2004). Systemni zv'iazky yurydychnykh dzherel prava: avtoref. dys. na zdobuttia nauk. stupenia kand. yuryd. nauk: 12.00.01 "Teoriia ta istoriia derzhavy i prava; istoriia politychnykh i pravorykh uchen" [Systematic chains of legal sources: The Abstract of the Thesis for a Candidate Degree in Legal Sciences: 12.00.01 "Theory and history of law and state; history of political and legal sciences"] (Kharkiv: KhNUIA).

Tsyvil'nyy procesualnyy kodeks 2004 (Verkhovna Rada Ukrayiny) [Civil Procedural Code 2004 (Verkhovna Rada of Ukraine)]. Ofitsiynyy sayt Verkhovnoyi Rady Ukrayiny [The official website of the Verkhovna Rada of Ukraine], retrieved from https://zakon.rada.gov.ua/laws/show/1618-15\#Text.

Uliotova, G. D. (2007). Istochniki ispolnitel'nogo prava Rossijskoj Federacii: avtoref. dis. na soiskanie uchenoj stepeni d-ra jurid. nauk: 12.00.03 "Grąhdanskoe pravo; predprinimatel'skoe pravo; semejnoe pravo; męhdunarodnoe chastnoe parvo" [Sources of enforcement law in Russian Federation: The Abstract of the Thesis for a Doctorate Degree in Juridical Science: 12.00.03 "Civil law and civil procedure, family law, private international law"] (Krasnodar: Kuban' state university).

Vasylenko, O. S. (2013). Osnovni zasoby harmonizatsii ta unifikatsii prava mizhnarodnoi torbivli $v$ diialnosti UNCITRAL [The basic means of harmonisation and unification of international trade law in UNCITRAL activities]. Chasopys Kyivskoho universytetu prava [The Bulletin of Kyiv University of Law], No. 3, 371-374.

Yarkov, V. V. (2017). Global'nyj kodeks prinuditel'nogo ispolnenija kak osnova garmonizacii ispolnitel'nogo proizvodstva [Global Code of Enforcement as a basis for the harmonization of enforcement procedure]. Zakon [Law], No. 7, 43-50.

Zakon Ukrayiny "Pro mizhnarodne pryvatne pravo" 2005 (Verkhovna Rada Ukrayiny). [The Law of Ukraine "On Private international law" 2005 (Verkhovna Rada of Ukraine)]. Ofitsiynyy sayt Verkbovnoyi Rady Ukrayiny [The official website of the Verkhovna Rada of Ukraine], retrieved from https://zakon.rada.gov.ua/laws/show/2709-15\#Text.

Zakon Ukrayiny "Pro organy i osib, yaki zdiisniuiut prymusove vykonannia sudovykh rishen i rishen inshykh orhaniv" 2016 (Verkhovna Rada Ukrayiny) [The Law of Ukraine "On Bodies and Persons who Carry out the Enforcement of Court Decisions and Acts of Other Authorities" 2016 (Verkhovna Rada of Ukraine)]. Ofitsiynyy sayt Verkhomoyi Rady Ukrayiny [The official website of the Verkhovna Rada of Ukraine], retrieved from https://zakon.rada.gov.ua/laws/show/1403-19\#Text.

Zakon Ukrayiny "Pro vykeonavche provadz̧hennia" 2016 (Verkhovna Rada Ukrayiny) [The Law of Ukraine "On Enforcement Procedure" 2016 (Verkhovna Rada of Ukraine)]. Ofitsiynyy sayt Verkhounoyi Rady Ukrayiny [The official website of the Verkhovna Rada of Ukraine], retrieved from https://zakon.rada.gov.ua/laws/show/1404-19\#Text. 
